\title{
Collapsibility and Volume Change Behavior of Unsaturated Residual Soil
}

\author{
${ }^{1}$ Azlan A. Aziz, ${ }^{2}$ Faisal Hj. Ali, ${ }^{2}$ Choong Foong Heng, ${ }^{1}$ Thamer Ahmed Mohammed \\ and ${ }^{1}$ Bujang B.K. Huat \\ ${ }^{1}$ Department of Civil Engineering, Universiti Putra Malaysia \\ ${ }^{2}$ Department of Civil Engineering, Universiti of Malaya, Malaysia
}

\begin{abstract}
Residual soils occur in most countries of the world but the greater areas and depths are normally found in tropical humid areas. In these places, the soil forming processes are still very active and the weathering development is much faster than the erosive factor. Most residual soil exhibit high suctions for most of the year. The absence of positive pore water pressure except immediately after rain, makes conventional soil mechanics for saturated soil not so relevant. Ignorance or lack of understanding of the geotechnical behavior of soil in the partially or unsaturated state has caused a lot of damages to infrastructures, buildings and other structures. For instance, the collapsibility and volume change of partially saturated soils in connection with the drying or wetting causes a lot of damage in foundation, roads and other structures. It is also observed that many shallow slope failures involve a slumping (collapse) type of failure. As such, the development of extended soil mechanics, which embraces the soil in the unsaturated state or subjected to soil suction, is essential. This study examines the collapsibility and volume change behavior specifically of an unsaturated residual soil under various levels of applied matric suction $\left(\mathrm{u}_{\mathrm{a}}-\mathrm{u}_{\mathrm{w}}\right)$ and net mean stress $\left(\sigma-\mathrm{u}_{\mathrm{a}}\right)$ in a predetermined stress path. The volume change of the soil is found to be sensitive to both the applied matric suction and net mean stress. The soil is found to exhibit a collapsibility behavior upon a reduction in applied matric suction at constant net mean stress.
\end{abstract}

Key words: Collapsibility, matric suction, residual soil, void ratio, volume change

\section{INTRODUCTION}

Residual soils occur in most countries of the world but the greater areas and depths are normally found in tropical humid areas. In these places, the residual soil (also known as tropical residual soils) forming processes are still very active and the weathering development is much faster than the erosive factor. The origin, formation and occurrence of tropical residual soils have been described in detail by Singh and Huat ${ }^{[1]}$.

Deep groundwater condition is not unusual in tropical residual soils especially within steep slopes. Soils above the groundwater is certainly unsaturated, hence negative pore water pressure also known as matric suction plays an important role in controlling the shear strength and consequently the stability of many steep slopes.

Most residual soil exhibit high suctions for most of the year. The absence of positive pore water pressure except immediately after rain, makes conventional soil mechanics for saturated soil not so relevant. In particular, the effective stress theories of saturated soil are not applicable at the practical level.

Ignorance or lack of understanding of the geotechnical behavior of soil in the partially or unsaturated state has caused a lot of damages to infrastructures, buildings and other structures. For instances, the collapsibility and volume change of partially saturated soils in connection with the drying or wetting causes a lot of damage in foundation, roads and other structures. It is also observed that many shallow slope failures involve a slumping (collapse) type of failure. As such, the development of extended soil mechanics, which embraces the soil in the unsaturated state or subjected to soil suction is essential.

As the name suggest, unsaturated soil means soil that is not fully saturated i.e. soils, which contain both air and water phases within its soils phase. However, in contrast with Bishop's ${ }^{[2]}$ concept of unsaturated soil, it is accepted that the state of stress in the water phase rather than the degree of saturation, that should be used $^{[3-5]}$.

The two stress state variables most commonly used are the net normal stress, $\left(\sigma-\mathrm{u}_{\mathrm{a}}\right)$ and the matric suction, $\left(u_{a}-u_{w}\right)$, which is found to be the most satisfactory for engineering purposes ${ }^{[3-8]}$. This combination has the advantage of only one stress state variable that is affected when the pore water pressure is changed. Or, in other words, effects of change in total normal stress can be separated from the effects caused by a change in the pore water pressure.

Numerous research have been done to study the volume change behavior of partially saturated soil, i.e. the swelling or collapsing behavior of soil upon wetting, or reduction in suction. Examples are given by El-Sohby and Rabbaa ${ }^{[9]}$, El-Sohby and Elleboudy ${ }^{[10]}$, 
Lawton et $a .^{[11]}$ and Tadepalli and Fredlund ${ }^{[12]}$. This study examines the collapsibility and volume change behavior specifically of an unsaturated residual soil under various levels of applied matric suction $\left(\mathrm{u}_{\mathrm{a}}-\mathrm{u}_{\mathrm{w}}\right)$ and net mean stress $\left(\sigma-u_{a}\right)$ in a predetermined stress path.

\section{EXPERIMENTAL SET-UP}

The conventional experimental set-up for the testing of fully saturated soil is not suitable to be used for the testing of unsaturated soil. In view of this, a special experimental set-up has been developed in order to perform the test program described in this study. With the specially developed experimental set-up, unsaturated soil can be tested with various levels of applied matric suction and net mean stress in a predetermined stress path. Both the overall (structural) volume change and water volume change of the soil sample can be monitored when the tests are performed.

In this study, a series of suction controlled isotropic compression tests are performed to determine the collapsibility and volume change of the unsaturated residual soil.

Figure 1 shows a schematic diagram of the experimental set-up. The test panel consists of a double-walled cell, volume change indicators, diffused air volume indicators, pressure application system, pressure transducers and pressure gauges. The results of the test were monitored and recorded by a data logger connected to a personal computer.

The suction was applied by means of axistranslation technique to avoid cavitations ${ }^{[13]}$. In this technique, the air pressure $\left(\mathrm{P}_{\mathrm{a}}\right)$ and back water pressure $\left(\mathrm{P}_{\mathrm{w}}\right)$ were applied on the soil sample. The difference between the air pressure $\left(\mathrm{P}_{\mathrm{a}}\right)$ and the back water pressure $\left(\mathrm{P}_{\mathrm{w}}\right)$ applied on the sample is taken as the applied matric suction $\left(\mathrm{P}_{\mathrm{a}}-\mathrm{P}_{\mathrm{w}}\right)$. In the study, the air pressure was applied to the top of the sample whereas the back water pressure was applied to bottom of the soil sample. The matric suction applied is not to exceed the air entry value of the high air entry ceramic disc at the pedestal of the cell.

Net mean stress applied to the samples in the study is taken as $\mathrm{P}-\mathrm{P}_{\mathrm{a}}$ where $\mathrm{P}$ is the all round cell pressure applied to the soil sample and $\mathrm{P}_{\mathrm{a}}$ is the air pressure applied to the top of the sample. The back water pressure was applied through an air/water bladder system and monitored by means of a pressure transducer. Another set of air/water bladder system with similar design is used for the application of cell pressure. The Wykeham Farrance constant pressure unit (motorized oil water system) is also used when the pressure applied exceeded $500 \mathrm{kPa}$.

The structural (overall) volume change and water phase volume change are measured by means of automatic volume change indicators. The pressure and volume change measured by the pressure transducers and volume change indicators were recorded by means of a data logger, which can then be retrieved by a personal computer.

In order to ensure that the triaxial cell does not experience significant volume change when the pressure is altered, a double-walled cell was specially designed and fabricated.

For soil sample, disturbed soils was obtained from a cut slope at KM 31 along the Karak-Kuala Lumpur Highway, Malaysia. The soil was a residual soil of weathering grade VI, based on the commonly used classification of Little ${ }^{[14]}$ and McLean and Gribble ${ }^{[15]}$, as shown in Table 1. The soil had been formed over commonly found porphyritic biotite granite bedrock of peninsular Malaysia ${ }^{[16]}$.

The soil sample was obtained at about 3 to 4 meters below the ground surface by means of auger. Table 2 shows the basic properties of the soil samples, which can be described as yellowish brown sandy clay. The soil sample is first air dried in the laboratory at room temperature for about 2 weeks, with lumps broken down by means of a rubber hammer. The airdried soil is then carefully and thoroughly mixed with a predetermined amount of distilled water, approximately $20 \%$, which is close to the optimum moisture content obtained from the standard Proctor compaction test. Static compaction is then carried out to mould the sample to ensure a homogeneous and identical sample. A similar compaction method has been applied by Booth $^{[17]}$ and Nagaraj and Murthy ${ }^{[18]}$.

\section{TEST PROGRAM}

The main objective of the study was to investigate the collapsibility and volume change behavior of a granitic residual soil when subjected to various levels of matric suction $\left(\mathrm{u}_{\mathrm{a}}-\mathrm{u}_{\mathrm{w}}\right)$ and net mean stress $\left(\sigma-\mathrm{u}_{\mathrm{a}}\right)$ in predetermined stress paths. The stress paths chosen are shown in Fig. 2 and shown in Table 3. Six statically compacted samples were tested, designated as S1, S2, S3, S4, S5 and S6.

Note that all the samples were subjected to preset matric suction throughout the test, except for sample S1.

For samples subjected to the matric suction, the air pressure applied to the samples was kept at $300 \mathrm{kPa}$ level throughout the test. The changes in the matric suction and net mean stress were performed by varying the back water pressure and cell pressure respectively. For the sample not subjected to the matric suction, the net mean stress was changed by varying the cell pressure whilst keeping the back water pressure at 300 $\mathrm{kPa}$ throughout the test.

\section{RESULTS AND DISCUSSION}

The plot of void ratio of the samples at various stress points versus the net mean stress is shown in Fig. 3. The net mean stresses are plotted both in normal and $\log$ scale. 


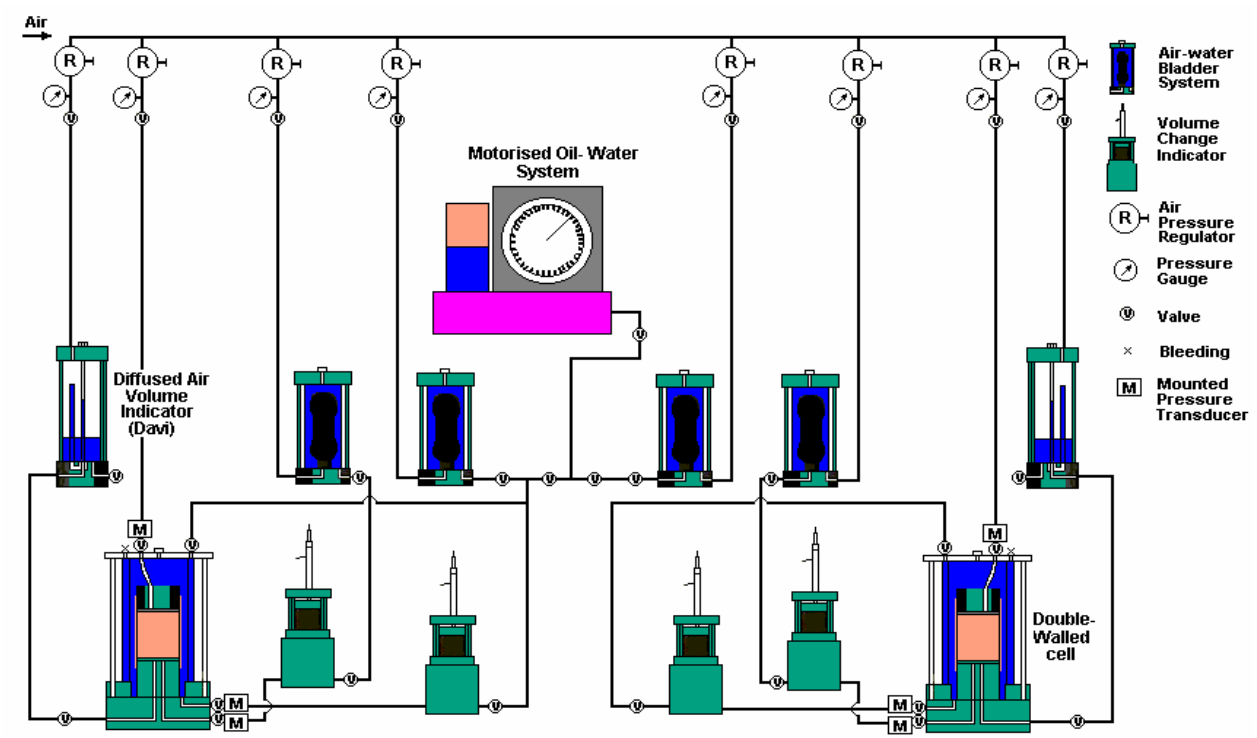

Fig. 1: Schematic diagram of the experimental set-up

Table 1: Classification of the weathering profile

\begin{tabular}{|c|c|c|}
\hline \multicolumn{2}{|c|}{ Weathering classification } & \multirow[t]{2}{*}{ Description } \\
\hline Term & Grade & \\
\hline Residual soil & VI & $\begin{array}{l}\text { All rock mater } \\
\text { destroyed; the } \\
\text { transported. }\end{array}$ \\
\hline Completely Weathered & V & $\begin{array}{l}\text { All rock mater } \\
\text { still largely in }\end{array}$ \\
\hline Highly Weathered & IV & $\begin{array}{l}\text { More than hal } \\
\text { discolored roc }\end{array}$ \\
\hline Moderately Weathered & III & $\begin{array}{l}\text { Less than half } \\
\text { discolored roc }\end{array}$ \\
\hline Slightly Weathered & II & $\begin{array}{l}\text { Discoloration } \\
\text { weathering m }\end{array}$ \\
\hline Fresh Rock & I & $\begin{array}{l}\text { No visible sig } \\
\text { discontinuity }\end{array}$ \\
\hline \multicolumn{3}{|c|}{ Source: McLean and Gribble ${ }^{[14]}$} \\
\hline \multicolumn{3}{|c|}{ Table 2: Basic properties of the residual soil sample } \\
\hline Liquid limit & & $98 \%$ \\
\hline Plastic limit & & $49 \%$ \\
\hline Optimum moisture cor & & $19.5 \%$ \\
\hline Maximum dry density & & $1.52 \mathrm{Mg} / \mathrm{m}^{3}$ \\
\hline Specific gravity & & 2.7 \\
\hline Sand content & & $45 \%$ \\
\hline Silt content & & $15 \%$ \\
\hline Clay content & & $40 \%$ \\
\hline Type of clay mineral ( & raction) & Kaolinite \\
\hline
\end{tabular}

For sample S1 which was not subjected to any matric suction throughout the test, the void ratio of the sample was found to decrease significantly as the net mean stress was elevated to higher levels in stress paths $\mathrm{A} 1 \rightarrow \mathrm{B} 1, \mathrm{~B} 1 \rightarrow \mathrm{C} 1, \mathrm{C} 1 \rightarrow \mathrm{D} 1, \mathrm{D} 1 \rightarrow \mathrm{E} 1, \mathrm{E} 1 \rightarrow \mathrm{F} 1$ and $\mathrm{F} 1 \rightarrow \mathrm{G} 1$, as shown in Fig. 3.

For the samples subjected to matric suction, the void ratio of the samples decreased when the applied matric suction was increased to the higher levels at net

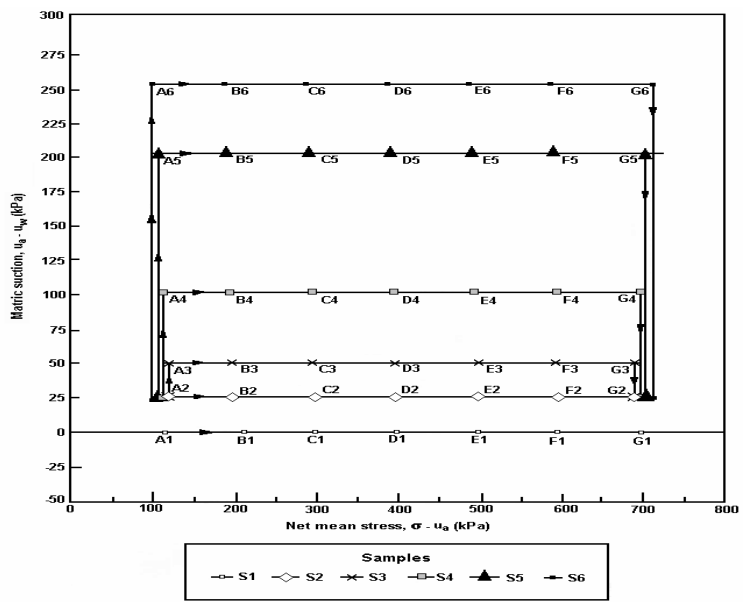

Fig. 2: Stress paths of samples tested

mean stress of $100 \mathrm{kPa}$. Similar report on the decrease in void ratio or volume of soil with an increase in matric suction was also made by Josa et al. ${ }^{[19]}$. 
Am. J. Environ. Sci., 2 (4): 161-166, 2006

Table 3: Stress paths of samples tested

\begin{tabular}{|c|c|c|c|c|c|c|c|c|}
\hline \multicolumn{3}{|c|}{ Sample S1 } & \multicolumn{3}{|c|}{ Sample S2 } & \multicolumn{3}{|l|}{ Sample 3} \\
\hline Stress & Net Mean & Matric & Stress & Net Mean & Matric & Stress Point & Net Mean & Matric \\
\hline Point & $\begin{array}{l}\text { Stress } \\
\left(\sigma-u_{a}\right) \\
(\mathrm{kPa})\end{array}$ & $\begin{array}{l}\text { Suction } \\
\left(\mathrm{u}_{\mathrm{a}}-\mathrm{u}_{\mathrm{w}}\right) \\
(\mathrm{kPa})\end{array}$ & Point & $\begin{array}{l}\text { Stress } \\
\left(\sigma-\mathrm{u}_{\mathrm{a}}\right) \\
(\mathrm{kPa})\end{array}$ & $\begin{array}{l}\text { Suction } \\
\left(\mathrm{u}_{\mathrm{a}}-\mathrm{u}_{\mathrm{w}}\right)(\mathrm{kPa}\end{array}$ & & $\begin{array}{l}\text { Stress } \\
\left(\sigma-\mathrm{u}_{\mathrm{a}}\right) \\
(\mathrm{kPa})\end{array}$ & $\begin{array}{l}\text { Suction } \\
\left(\mathrm{u}_{\mathrm{a}}-\mathrm{u}_{\mathrm{w}}\right)(\mathrm{kPa}\end{array}$ \\
\hline A1 & 100 & 0 & A2 & 100 & 25 & A2 & 100 & 25 \\
\hline- & - & - & - & - & - & A3 & 100 & 50 \\
\hline B1 & 200 & 0 & B2 & 200 & 25 & B3 & 200 & 50 \\
\hline $\mathrm{C} 1$ & 300 & 0 & $\mathrm{C} 2$ & 300 & 25 & $\mathrm{C} 3$ & 300 & 50 \\
\hline D1 & 400 & 0 & $\mathrm{D} 2$ & 400 & 25 & D3 & 400 & 50 \\
\hline E1 & 500 & 0 & E2 & 500 & 25 & E3 & 500 & 50 \\
\hline F1 & 600 & 0 & F2 & 600 & 25 & F3 & 600 & 50 \\
\hline G1 & 700 & 0 & G2 & 700 & 25 & G3 & 700 & 50 \\
\hline- & - & - & - & - & - & G2 & 700 & 25 \\
\hline \multicolumn{3}{|c|}{ Sample S4 } & \multicolumn{3}{|c|}{ Sample S5 } & \multicolumn{3}{|l|}{ Sample S6 } \\
\hline Stress & Net Mean & Matric & Stress & Net Mean & Matric & Stress Point & Net Mean & Matric \\
\hline Point & $\begin{array}{l}\text { Stress } \\
\left(\sigma-\mathrm{u}_{\mathrm{a}}\right) \\
(\mathrm{kPa})\end{array}$ & $\begin{array}{l}\text { Suction } \\
\left(\mathrm{u}_{\mathrm{a}}-\mathrm{u}_{\mathrm{w}}\right)(\mathrm{kPa}\end{array}$ & Point & $\begin{array}{l}\text { Stress } \\
\left(\sigma-\mathrm{u}_{\mathrm{a}}\right) \\
(\mathrm{kPa})\end{array}$ & $\begin{array}{l}\text { Suction } \\
\left(\mathrm{u}_{\mathrm{a}}-\mathrm{u}_{\mathrm{w}}\right)(\mathrm{kPa}\end{array}$ & & $\begin{array}{l}\text { Stress } \\
\left(\sigma-\mathrm{u}_{\mathrm{a}}\right) \\
(\mathrm{kPa})\end{array}$ & $\begin{array}{l}\text { Suction } \\
\left(\mathrm{u}_{\mathrm{a}}-\mathrm{u}_{\mathrm{w}}\right) \\
(\mathrm{kPa})\end{array}$ \\
\hline A2 & 100 & 25 & A2 & 100 & 25 & A2 & 100 & 25 \\
\hline A4 & 100 & 100 & A5 & 100 & 200 & A6 & 100 & 250 \\
\hline B4 & 200 & 100 & B5 & 200 & 200 & B6 & 200 & 250 \\
\hline $\mathrm{C} 4$ & 300 & 100 & $\mathrm{C} 5$ & 300 & 200 & C6 & 300 & 250 \\
\hline D4 & 400 & 100 & D5 & 400 & 200 & D6 & 400 & 250 \\
\hline E4 & 500 & 100 & E5 & 500 & 200 & E6 & 500 & 250 \\
\hline $\mathrm{F} 4$ & 600 & 100 & F5 & 600 & 200 & F6 & 600 & 250 \\
\hline G4 & 700 & 100 & G5 & 700 & 200 & G6 & 700 & 250 \\
\hline G2 & 700 & 25 & G2 & 700 & 25 & $\mathrm{G} 2$ & 700 & 25 \\
\hline
\end{tabular}

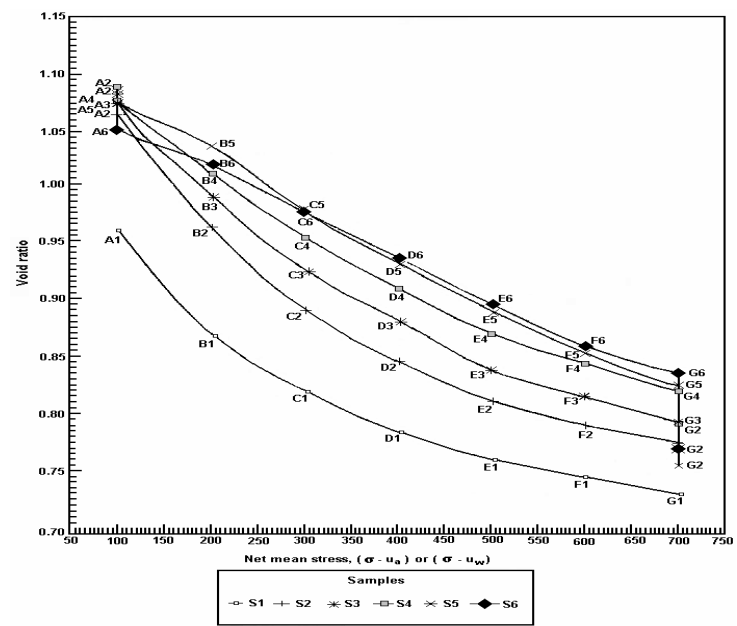

(a)

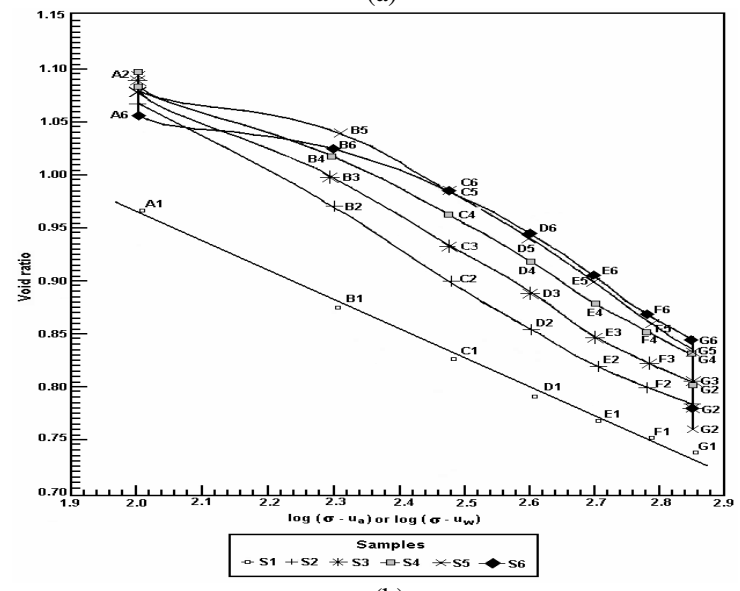

(b)

Fig. 3: Void ratio of samples at various stress points
Samples subjected to matric suction (S2, S3, S4, S5 and S6) experienced a further decrease in void ratio when the net mean stress was increased to higher levels at constant matric suction condition.

In the last stress path where the matric suction was reduced to $25 \mathrm{kPa}$ at constant applied net mean stress of $700 \mathrm{kPa}$, these samples again showed a decrease in the void ratio. The decrease in void ratio as a result of reduction of matric suction is normally termed as collapse. Similar collapsible behavior upon reduction of matric suction or upon wetting at constant net mean stress (or applied stress) was also reported by researchers such as El Sohby and Rabbaa ${ }^{[9]}$, El-Sohby and Elleboudy ${ }^{[10]}$, Lawton et al. ${ }^{[11]}$ and Tadepalli and Fredlund $^{[12]}$.

It is of interest to note that at all levels of net mean stress, the void ratio of the samples (S2, S3, S4, S5 and S6) subjected to matric suction were significantly greater than that of the sample (S1) which was not subjected to matric suction throughout the test. For instance, sample S2 that was only subjected to a matric suction of $25 \mathrm{kPa}$, the void ratio of the sample was greater than that of sample S1 by approximately 0.10 at net mean stress of $100 \mathrm{kPa}$ and approximately 0.05 at net mean stress of $700 \mathrm{kPa}$. The void ratio of sample S6 which was subjected to a matric suction of $250 \mathrm{kPa}$ was found to be greater than that of sample S1 by as significant as approximately 0.16 at net mean stress of $300 \mathrm{kPa}$. In addition, this difference in void ratio (between sample subjected to matric suction and sample not subjected to the matric suction) appeared to be relatively greater at lower net mean stress level and smaller at higher level of net mean stress. 
The significant difference in void ratio showed that the matric suction applied on the sample appeared to have contributed to a pronounce effect on the volume change of the soil. It appears that the matric suction has provided an additional rigidity to the soil structure. This has in turn helped the soil to withstand greater net mean stress at a given void ratio or in other words, withstand a given net mean stress at a significantly greater void ratio. This could be the main reason why at a given net mean stress, the void ratio of samples subjected to the matric suction appeared to be significantly greater than that of sample not subjected to the applied matric suction.

The effect of the additional rigidity from the matric suction to the soil structure appeared to increase as the matric suction applied on the sample was increased. From Fig. 3, it can be noted that the void ratio of the sample subjected to higher matric suction was generally greater than that of sample subjected to lower matric suction. This is particularly apparent at the higher net mean stress levels.

However, when the applied matric suction was reduced to $25 \mathrm{kPa}$, the additional rigidity appears to decrease accordingly. The decrease in the additional rigidity would have then caused the instability of the soil structure and consequentially led to a collapses or reduction in void ratio without an increase in applied net mean stress.

Upon the reduction of the applied matric suction, it should be noted that samples S2, S3, S4, S5 and S6 were actually at the same stress point, G2 where the net mean stress and matric suction applied on the samples were similar. It is interesting to note that the void ratio of these samples appeared to be approximately close to each other at this stress point. This seems to suggest that there could be a uniqueness in the void ratio or at least an approximation to a uniqueness which represent a unique relationship between the void ratio of the soil and the stress variables i.e. matric suction and net mean stress. The similar uniqueness was also observed by Fredlund and Morgenstern ${ }^{[3]}$.

The collapsible behavior of the soil has a significant implication on the practical aspects of geotechnical design. When the unsaturated residual soil is used to construct an engineering structure such as an embankment, the soil is expected to experience suction if the structure is above the water table. The overburden pressure applied on the soil will gradually increase as the thickness of the soil increases during the construction stage. If the predicted settlement is derived from a conventional oedometer test (which is normally rewetted prior to the test), the actual settlement at the site caused by the increase in overburden pressure is therefore expected to be lower than the predicted value. However, after the completion of the project, the water table may rise due to the development at the adjacent area or due to other reasons, the matric suction of the soil would then decrease and thus collapse or serious settlement may occur. This would in turn cause serious damage to the structure constructed at such filled area.

\section{CONCLUSION}

From the results of this study, the following conclusions can be made with regard to the collapsibility and volume change behavior of unsaturated residual soil subjected to various levels of net mean stress and matric suction.

When the applied matric suction is first increased at constant net mean stress condition, the void ratio of the soil generally decreased. When the net mean stress is increased to higher levels at constant matric suction, the soil experience a further decrease in void ratio.

There is an apparent unique relationship between the void ratio, matric suction and net mean stress. The uniqueness in void ratio is observed when there is collapse (decrease in void ratio) due to the reduction in applied matric suction at constant net mean stress. This decrease (collapse) in void ratio is believed to be due to loss of additional rigidity provided by the suction to the soil structure as the suction is suddenly reduced.

At a similar net mean stress level, the void ratio of the soil subjected to matric suction of even as low as 25 $\mathrm{kPa}$ appear to have marked difference from soil not subjected to matric suction. Generally, when the soil is at a similar level of net mean stress, the void ratio of the soil subjected to applied matric suction is found to be significantly greater than that of samples not subjected to applied matric suction due to the additional rigidity provided by the matric suction to the soil structure.

\section{REFERENCES}

1. Singh, H. and B.B.K. Huat, 2004. Origin, formation and occurrence of tropical residual soils. Tropical Residual Soils Engineering. Huat et al. (Ed). Leiden. Balkema, pp: 1-20.

2. Bishop, A.W., 1959. The principle of effective stress. Teknish, Ukefland, 106: 359-383.

3. Fredlund, D.G. and N.R. Morgenstern, 1976. Constitutive relation for volume change in unsaturated soils. Can. Geotech. J., 13: 261-276.

4. Fredlund, D.G. and N.R. Mongenstern, 1977. Stress state variables for unsaturated soils. ASCE J. Geotech. Engg.. 103: 447-466.

5. Fredlund, D.G. and H. Rahardjo, 1993. Soil Mechanics for Unsaturated Soil. New York. John Wiley and Sons.

6. Fredlund, D.G., 1978. Appropriate concepts and technology for unsaturated soils. Second Canadian Geoetchnical Colloqium, 121-139.

7. Fredlund, D.G., 1979. Second Canadian colloquium: Appropriate concepts and technology for saturated soils. Can. Geotech. J., 16: 121-139. 
8. Fredlund, D.G., N.R. Mongenstern and R.A. Widger, 1978. The shear strength of unsaturated soils. Can. Geotech. J., 15: 313-321.

9. El-Sohby, M.A. and A.A. Rabbaa, 1984. Deformation behavior of unsaturated soil upon wetting. Proceedings of the $8^{\text {th }}$ Regional Conference for Africa on Soil Mechanics and Foundation Engineering, Harare, pp: 129-137.

10. El-Sohby, M.A. and A.M. Elleboudy, 1987. Swelling and collapsible behavior of cemented sand upon wetting. Proc. $9^{\text {th }}$ Eur. Conf. on Soil Mechanics and Foundation Engineering, 2: 553556.

11. Lawton, E.C., R.J. Fragaszy and J.H. Hardcastle, 1989. Collapse of compacted clayey sand. ASCE J. Geotech. Engg,. 115: 1252-1267.

12. Tadepalli, R. and D.G. Fredlund, 1991. The collapse behavior of a compacted soil during inundation. Can. Geotech. J., 28: 447-488.

13. Hilf, J.W., 1956. An investigation of pore water pressure in compacted cohesive soils. Tech. Memorandum No. 654, Bureau of Reclamation. US Dept. of Interior.
14. Little, A.L., 1969. The engineering classification of residual tropical soils. Proc. $7^{\text {th }}$ Intl. Conf. Soil Mechanics and Foundation Engineering, Mexico, 1: 1-10.

15. McLean, A.C. and C.D. Gribble, 1979. Geology for civil engineers. London: $\mathrm{E}$ and FN Spon.

16. Raj, J.K., 1985. Characterization of the weathering profile developed over a porphyritic granite in Peninsular Malaysia. Bull. Intl. Assoc. Engg. Geol. Paris, 32: 121-128.

17. Booth, A.R., 1975. The factors influencing collapse settlement in compacted soils. Proc. $4^{\text {th }}$ Intl. Conf. Expansive Soil. Colorado, pp: 117-134.

18. Nagaraj, T.S. and B.R.S. Murthy, 1985. Compressibility of partially saturated soil. ASCE J. Geotech. Engg., 111: 937-942.

19. Josa, A., E.E. Alonso, A. Lloret and A. Gen, 1987. Stress-strain behavior of partially saturated soils. Proc. $9^{\text {th }}$ Eur. Conf. Soil Mechanics and Foundation Engg., 2: 561-564. 